B A N D $4, \quad 20019$

S E I T E $28-52$

D O I : $10.2478 / \mathrm{ADH}-2019-0003$

\title{
How the File was Invented
}

\author{
MICHAEL MOSS, DAVID THOMAS
}

This article traces the development of the use of the file in English administration and in the administration of the British Empire from its beginning to the digital era. It is very tempting to reify the file as something it was not and that in some ways it is a token of modernity which it is not either. In the British administration, it is simply an outcome of a long drawn-out process to organise as cheaply as possible the records of administration and the courts. There was never any serious attempt to develop coherent systems across the whole of government. There was always room for a variety of practice, largely because ministers and civil servants resented interference in their departments, particularly by the Treasury which had to sanction any increase in expenditure on what were regarded as backoffice functions. For this reason, change was always incremental across departments even if mandated centrally. Despite the establishment of the Treasury O\&M department in 1919 modelled on private sector practice, largely at first only to audit and approve registry systems, there was still plenty of variation in practice. This was because recommendations to overhaul the whole machinery of government in the light of wartime experience were for the most part ignored. ${ }^{1}$ Retrieval often depended as much on the memory of civil servants, particularly registry clerks, as on what were never much more than rudimentary finding aids. Until the Public Record Office (now The National Archives [TNA]) was established, there was no attempt effectively to continue to keep older records accessible and the same was true throughout the Empire.

\section{English Administrative Background}

There are two defining features of English administration which impacted on the development of the file. First, England is a common law country and so the sort of notarial documents which are found in Scottish, European and American archives are rarely found in England. Second, the overriding theme of English administration from the parsimony of Queen Elizabeth I onwards was a strong belief in economy and small government. As the utilitarian philosopher and political economist Jeremy Bentham put it:

We have seen above the grounds on which the general rule in this behalf - Be quiet - rests. Whatever measures, therefore, cannot be justified as exceptions to that rule, may be considered as non agenda on the part of government. The art, therefore, is reduced within a small compass: security and freedom are all that industry requires. The request which agriculture, 
manufactures, and commerce present to governments, is modest and reasonable as that which Diogenes made to Alexander: 'Stand out of my sunshiner. We have no need of favour - we require only a secure and open path. ${ }^{2}$

His disciple John Stuart Mill developed this principle into his famous doctrine of laissez faire that did not entirely exclude necessary government intervention. ${ }^{3}$ Economy remained and still remains the touchstone of British public administration, only interrupted by the exigency of war, but even then quickly readjusted on the return to peace, even after 1919. Despite the advent of the welfare state, such attitudes persist. In the authors' experience, record-keeping and registries have a very low priority and are often poorly staffed and inadequately resourced. Against this background, record-keeping was primarily a means of establishing precedent and protecting public servants' fiduciary responsibility. Registries across UK government are often regarded as a necessary evil rather than a store of useful knowledge.

Until the $17^{\text {th }}$ century, the vast bulk of English administration was conducted by courts of law. When Henry VIII abolished the monasteries in England and Wales (1536-1540), an administrative apparatus was urgently required to seize and administer their lands. ${ }^{4}$ The solution was not a new bureaucracy but a new court - the Court of Augmentations of the King's Revenue. The courts normally filed their records by type and date which were usually catalogued by the names of persons involved in legal actions.

From the $15^{\text {th }}$ century, political matters were handled by the king or queen's secretaries of state and from 1660 their roles were split into two departments: Northern and Southern. Southern dealt with Southern England, Wales, Ireland, the American colonies and relations with the Roman Catholic and Muslim states of Europe. Northern was responsible for Northern England, Scotland and relations with the Protestant states of northern Europe. In 1782, home affairs were transferred to the Home Office and the Foreign Office was established. Out of this reorganisation emerged two establishments, the home civil service and the foreign service, each with their own distinctive methods of increasing importance of colonial territories as a result of the war with France (1794-1815), the War Office was renamed as the War and Colonial Office. The Colonial Office was established as a separate department in 1854 but did not have control of all overseas territories. ${ }^{5}$

Diplomatic correspondence of the type handled by the Northern and Southern departments was filed by location and then by date, for example letters from Livorno would be filed under correspondence with Livorno and then by year.

India and parts of the Middle East were administered by the East India Company which was founded in 1600. A critical component in record-keeping in the administration of India were the so-called General Letters that were exchanged with London every year from the $17^{\text {th }}$ century and "written under the eye of the President of the Council with the utmost brevity and clearness, and with an intimate and exhaustive knowledge on the part of the writer of the whole of the subject matter of the proceedings of the year «. ${ }^{6}$ After the Indian revolution in 1857, India was placed under direct rule and the India Office was established in London, while the administration in India became the responsibility of the viceroy. Although aligned with the Foreign Office, India developed its own distinctive record-keeping systems that were based in part on those of the East India Company. Oddly throughout the history of British administration of India, civil servants in the India Office rarely if ever visited the subcontinent and often had only scant or hearsay knowledge of the country and its people. ${ }^{7}$ The same was true of most colonial possessions, as contrary to external perception that British governments had little real interest in the Empire until it was challenged in the late $19^{\text {th }}$ century. ${ }^{8}$

\section{Filing}

As we will see, the development of the file was a stepchange from the chronological methods of filing which had been used in courts and in diplomatic correspondence. The file allowed papers on the same subject to be brought together in the same place so that all the records relating to a single matter were to hand for a civil servant or minister to deal with. Careful filing of papers was regarded by observers as a key to 
effective administration. In looking back nostalgically on his early days in the civil service in his book "British Government in Crisis«, Sir Christopher Foster praised the record-keeping practices of the civil servants he encountered:

Underpinning their knowledge of their jobs was an exhaustive, but marvellous, filing system. Everything was written down. Almost every meeting discussed a paper, which was revised as it rose through the hierarchy towards the minister or was sent down again by her. (There was no problem identifying who suggested, and who authorised, every change to a paper, as there was to the 2002 Iraq dossier.) Every meeting, every lunch, was minuted. ${ }^{9}$

Lord Panmure, then Secretary of State for War, observed during discussion of the formation of the War Office registry in 1855: "The great desiderata for the easy and efficient discharge of the duty of a public office is a simple and efficient system of registration of the papers of the department «. ${ }^{10}$

Civil servants were heavily reliant on a small band of skilled and experienced, albeit poorly paid, registry clerks, to create new files, put papers away on the relevant file, index them and recover them when required. Some clerks seem to have devoted their lives to this work. It was tedious work, but it underpinned the effective management of government in the United Kingdom, India, the dominions and colonies. Systems were not always perfect and one of the authors of this contribution can remember how senior staff kept small notebooks containing the numbers of important files so that they could order them from the registry. When someone stidied away، such a notebook belonging to a former colleague, he spent days saying: "I have lost my memory«.

\section{The Docket}

As across most written cultures, the foundation of modern administration was the filing of dockets that recorded transactions. They were always a single item, normally dealing with a single subject and referenced endorsed on the verso (back) of the second fold with an explanation of what the docket was about (see Figs. 1 and 2). In other parts of Europe, such as Venice, they were stored flat, but still endorsed on the verso. ${ }^{11}$ All dockets were registered. Clerks not only summarised the content on the verso, but also wrote a minute on the action to be taken. Sometimes this content took the form of an extended note on the verso, but more often written on a separate sheet, folded with the docket and tied together with tape.

The registers, for example, for Treasury dockets in TNA at Kew, begin in $1557 .{ }^{12}$ Dockets were indexed alphabetically by name and under a rudimentary file plan, also organised alphabetically and by subject headings that were administered by the registry clerks. Each docket was numbered sequentially, and a skeleton register was compiled to show where they were stored (see Figs. 3 and 4).

These registers also show if a docket has been destroyed or transferred to be stored with another docket. ${ }^{13}$ Civil servants, as a result, were very dependent on registry clerks or their own memory to recover records. Assemblies of dockets on a common subject came to be known as long papers bundles and could extend over several decades. For example, TNA T1/3455 is "Long Papers, bundle 43: Charles Blackador, Deputy Assistant Commissory General: court martialled in Halifax, Nova Scotia, June 1822 and convicted of failure to exhibit sums of public money due: petitions for reinstatement, 1790-1840 « whereas TNA T1/4303 is "Long Papers, bundle 768: Tortola: liberated Africans, 1790-1840«. Long bundles were the responsibility of précis writers whose job was to summarise their contents as they required "more time than can be bestowed upon them by Clerks who are charged with the execution of the current business «. ${ }^{14}$ The records are kept at the UK National Archive at Kew (TNA) in the series T1. Each bundle in the sequential series is given a separate number, for example, T1/99. Most dockets, however, are stored separately and after 1777 they can only be located by using the registers in the series $\mathrm{T} 2$ and the skeleton registers in the series $\mathrm{T} 3$ and then ordering them from T1 where they are stored (see Figs. 3-6). The majority of dockets are incoming documents, letters, accounts, reports and so on. Some have actions noted on them and some include copies of replies, but 


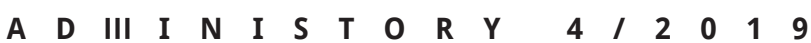

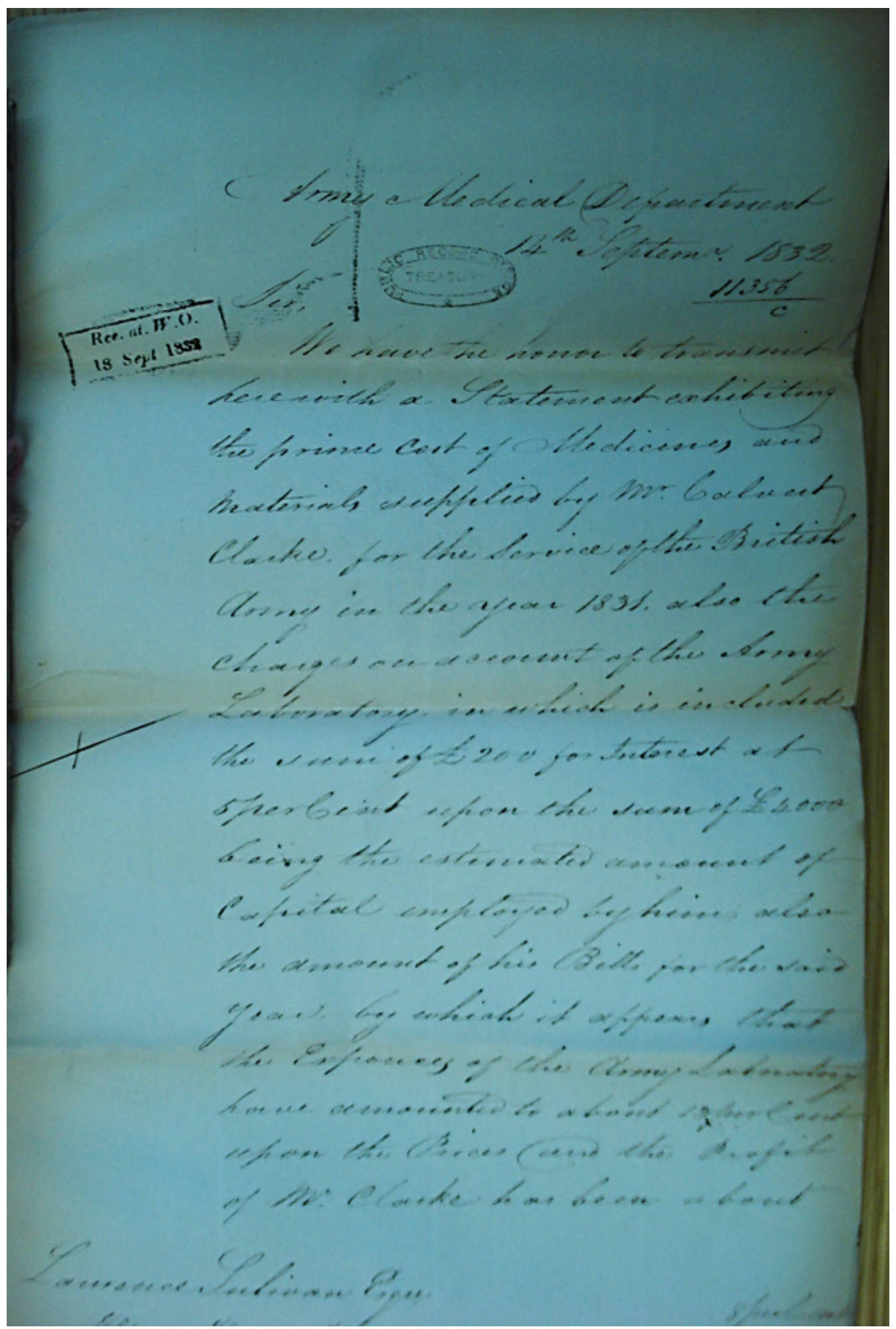

Figure 1: An open docket that clearly shows the fold lines. The letter is included at the top the reference number of the previous docket and is stamped by the War Office Registry clerk on receipt. (Source: TNA T1) 


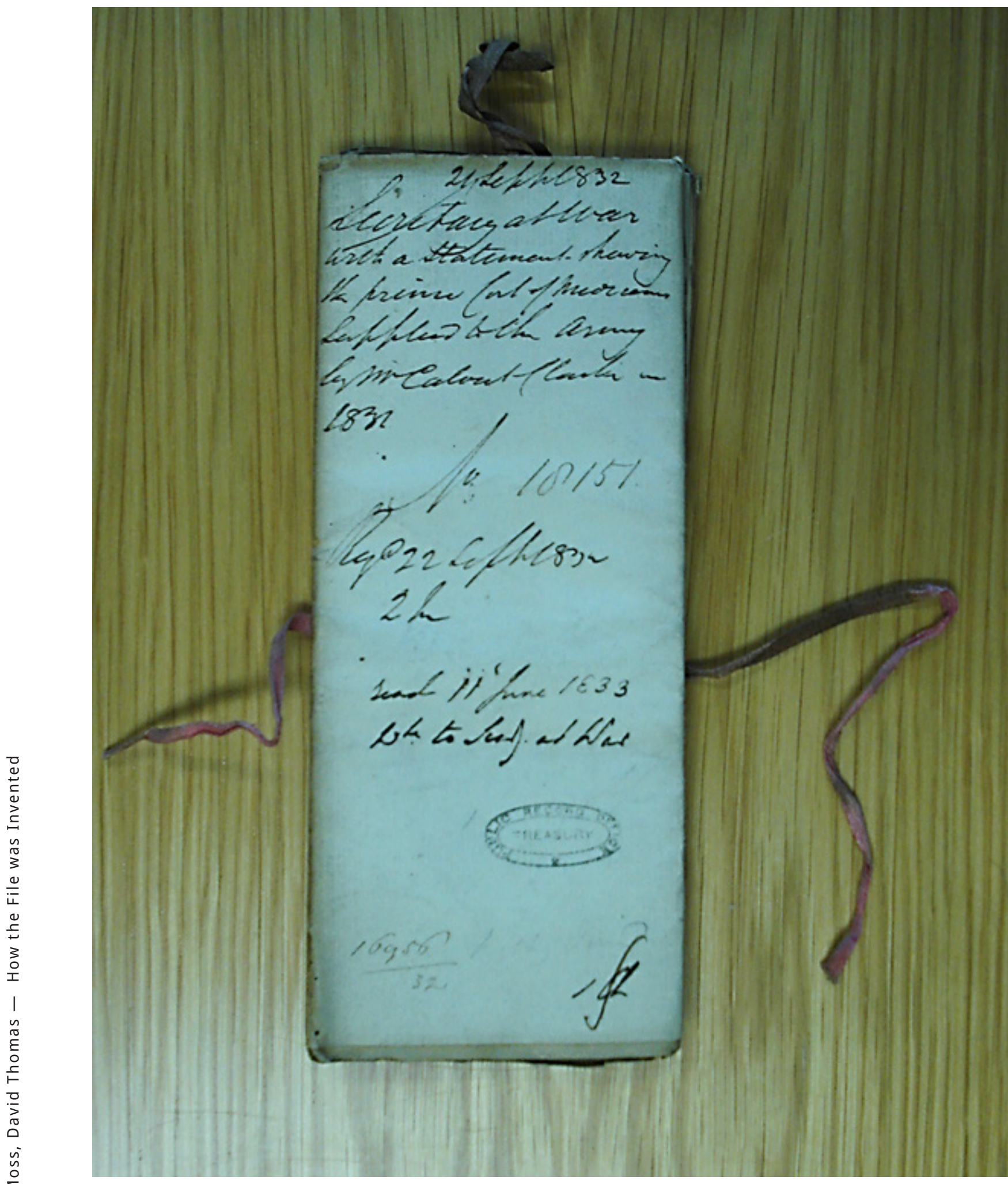

Figure 2: A folded docket with the red tape untied, dated 21 September 1832 with a brief description of the content beneath - Secretary at War showing the prime cost of medicines supplied to the Army by Mr Calvert Clarke in 1831. Beneath is the sequential number allotted when the docket was registered, 18151 and note stating that it was read by the Secretary at War on 11 June 1833 . The number at the bottom left is where the subsequent docket can be found. (Source: TNA T1) 


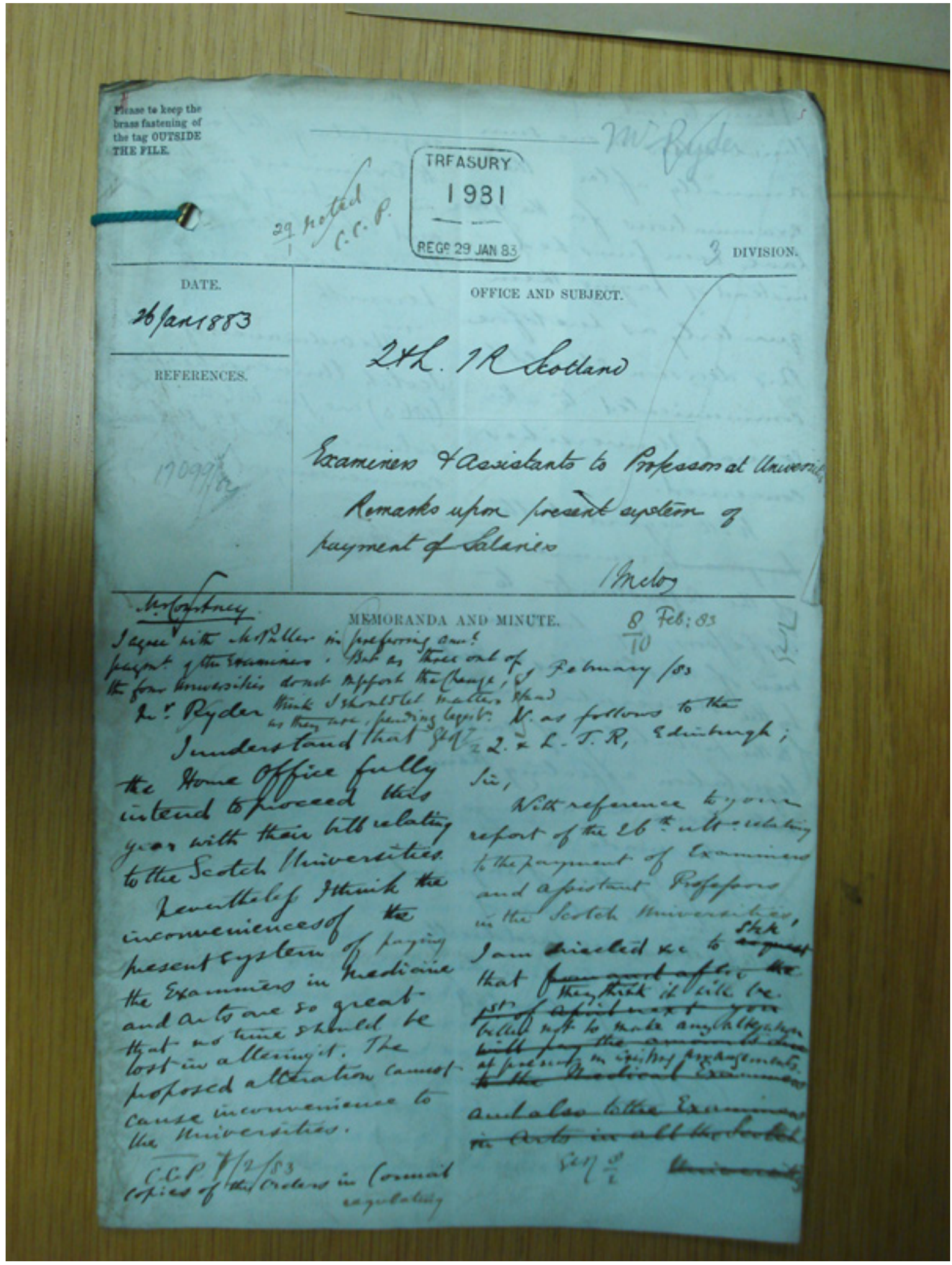

Figure 3: A jacketed docket with the memorandum and minute on the cover sheet and the reference number 1981. The title that refers to the Queen and Lord Rememberancer of Scotland (QLTR) with the subject beneath. The docket number is 1981 and the date is 26 January 1883. (Source: TNA T1) 


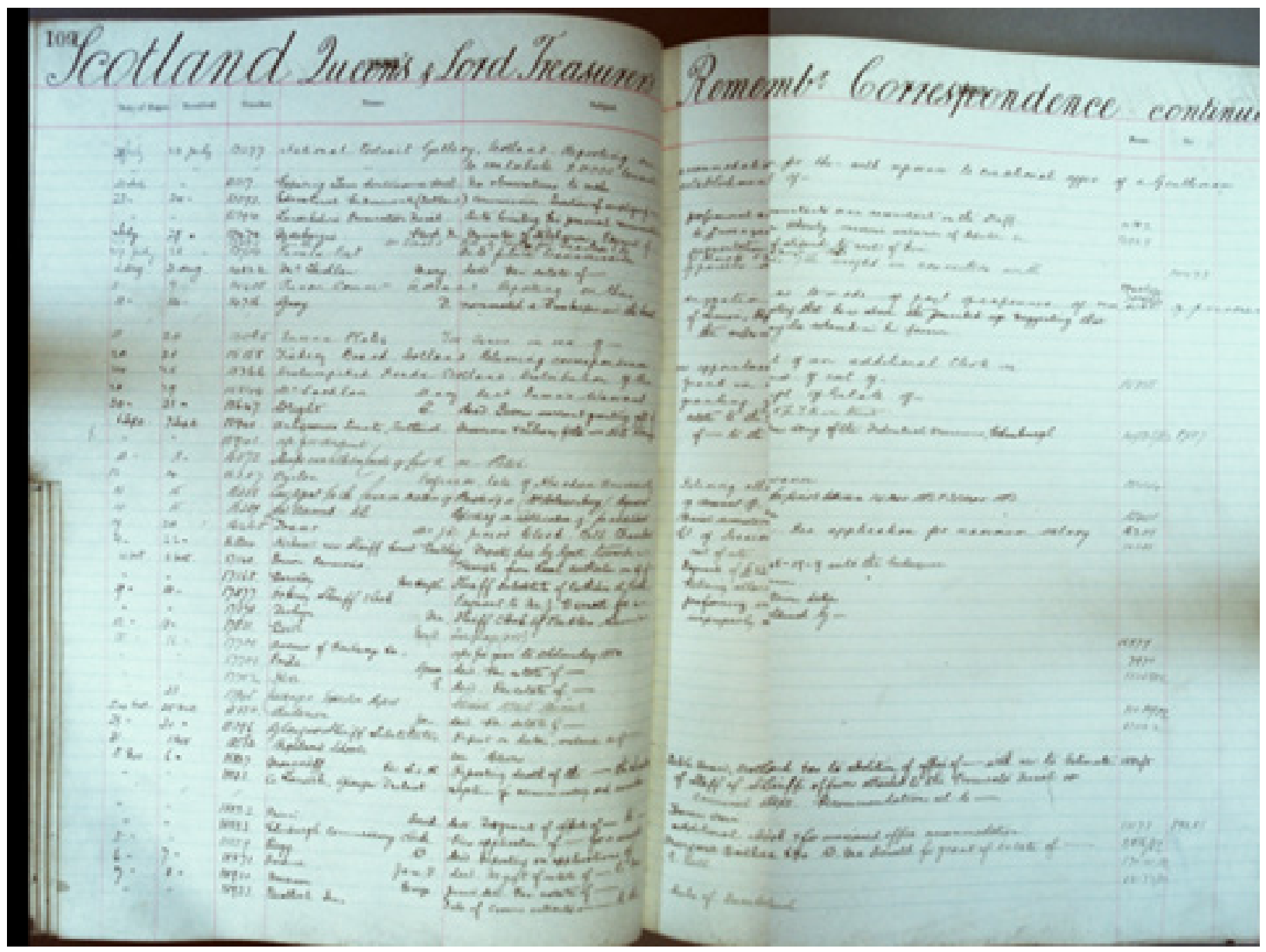

Figure 4: The page of the Treasury register, in which dockets relating to the QLTR were registered in a rudimentary file plan, listing date, docket numbers, name, subject and remarks. (Source: TNA T2: Registers of Papers)

most responses were copied in to letter books. SP 44/162 at the TNA contains the King's letters 1689-1776.

Practice varied from department to department and was jealously guarded. In the Treasury, filing was the responsibility of the Registry, whereas in the Foreign Office, the Board of Trade and the Irish Office it was handled by the Library. The Library in the Foreign Office was formally instituted in 1801 to be seemingly what Bruno Latour would term "a centre of calculation " $^{15}$ for the simple reason that most foreign office officials and ministers were very dependent on the library staff to translate and compile reports. ${ }^{16}$ Although the library had the appearance of a centre of accumulation, it did not represent an organised body of knowledge providing systematic reference. The nearest the United Kingdom had to such a concept were the collections
Hooker who inaugurated the Museum of Economic Botany in $1847 .{ }^{17}$

The Foreign Office library not only acquired, documented and managed collections of books and papers but also

managed the correspondence files of the office, had custody of all treaties with foreign powers, undertook research on all aspects of international affairs at the request of ministers and others, provided guidance as to precedent in affairs of state and was the author of numerous reports and memoranda on international affairs. $^{18}$

From 1810 to 1890, a brief summary of every document received or dispatched was "entered in a diary and a docket made on the document itself«. There was no central 


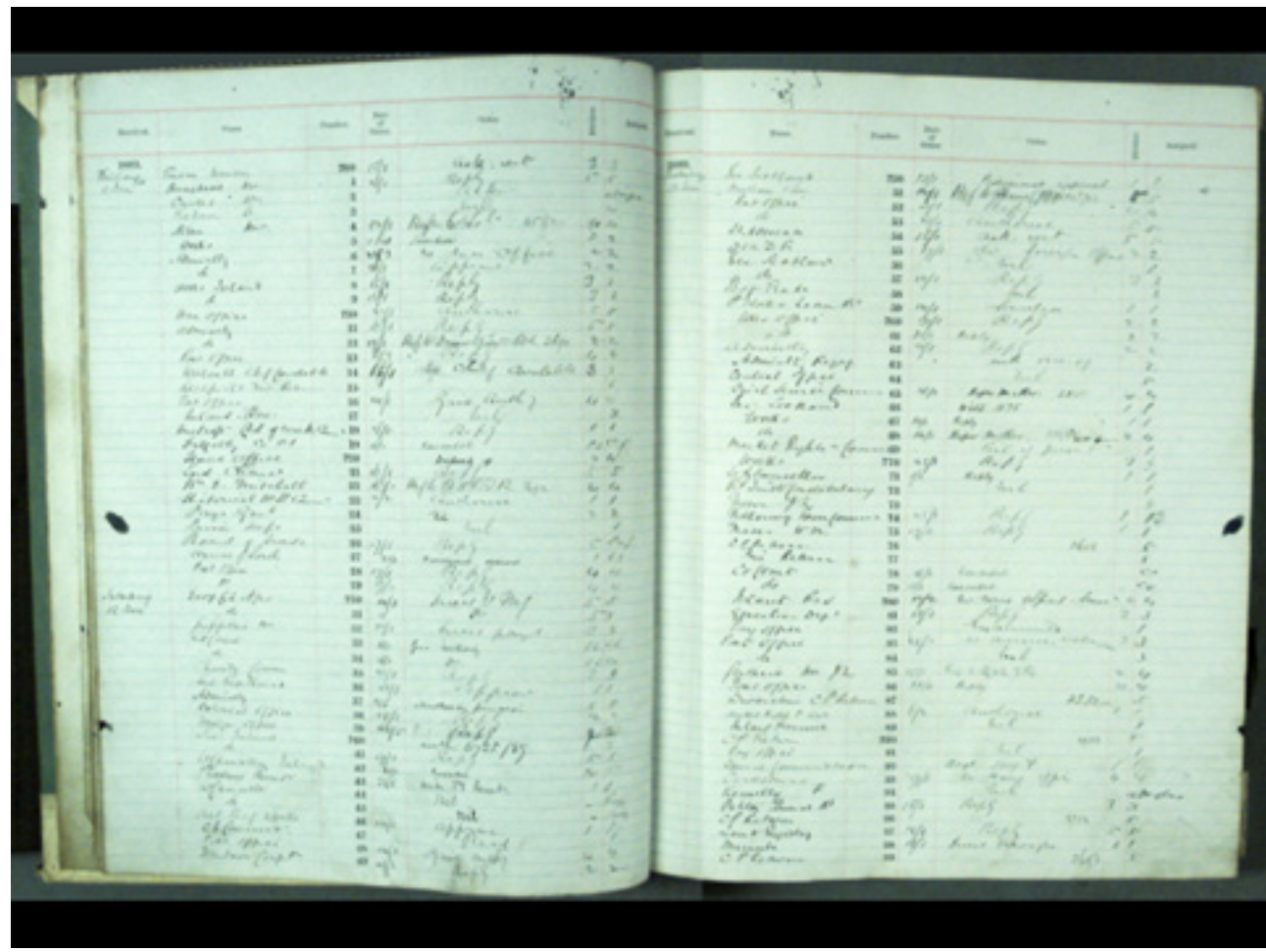

Figure 5: The Treasury register listing dockets sequentially with a note of action taken. (Source: TNA T3 Treasury: Skeleton Registers)

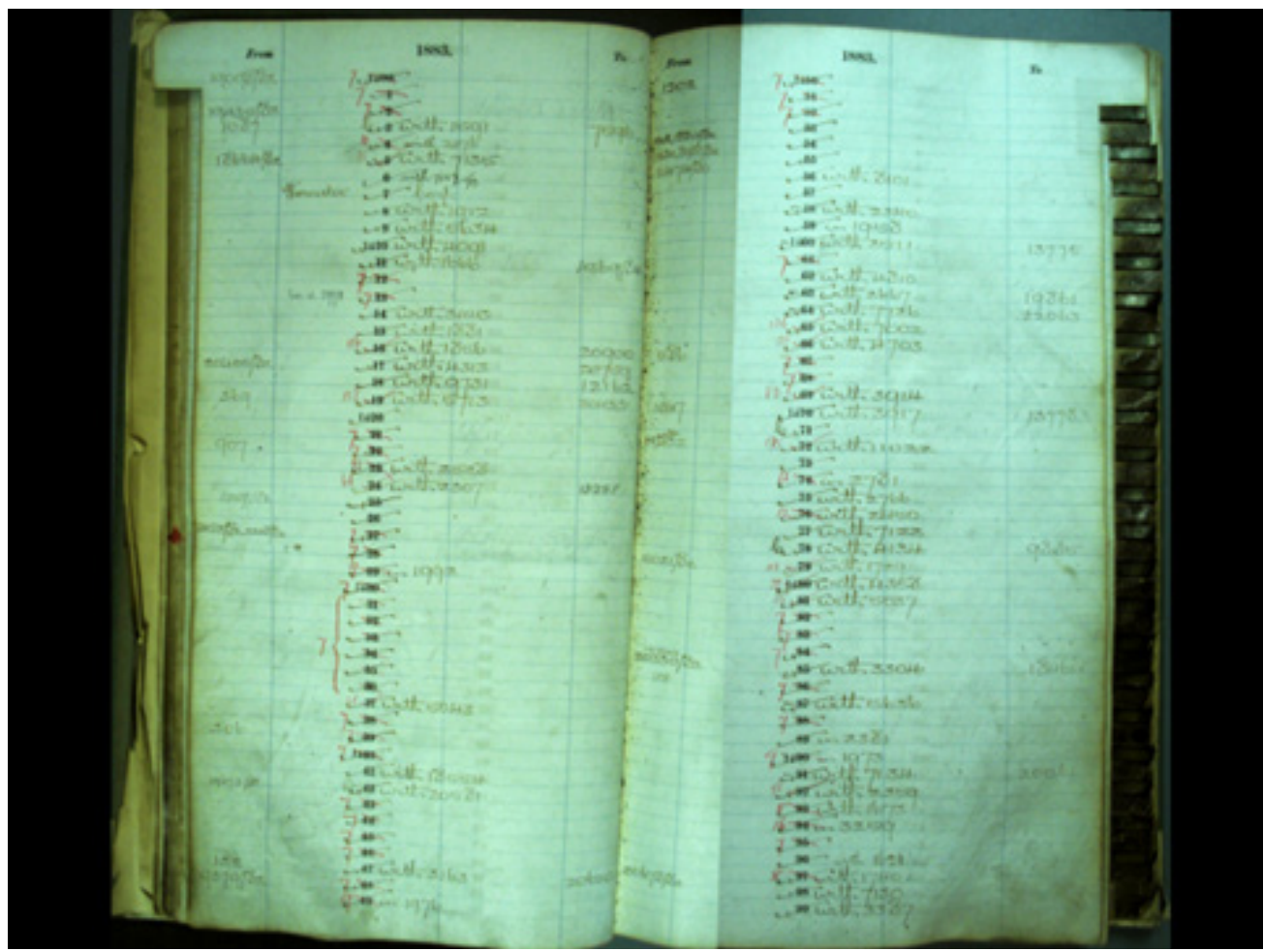

Figure 6: The Treasury skeleton register showing where dockets were stored and indicating if they had been amalgamated with other dockets or destroyed. (Source: TNA T3 Treasury: Skeleton Registers) 
registry, each department did its own filing and after 6 years the administration transferred files to the Record Office in the Library where an indexed register was compiled. ${ }^{19}$ Although there was a logic to combining the library with the registry as the same indexing terms were used by both, in practice they tended to function independently. ${ }^{20}$ Large spending departments, such as the Board of Ordnance, which was responsible for the procurement of all military materials, and the Victualling Board, which was responsible for purchasing food for the navy, linked their registers to hugely complex and cumbersome ledgers that recorded expenditure. During the French Wars (1794-1815), both these offices oversaw huge expenditure and very lengthy and critical supply chains. ${ }^{21}$

Before dockets were stored or sput away in the registry‘, normally after 6 months, they were sorted in pigeonholes under the headings in the registers. Writing in 1870 R. W. Lapper, who worked at the headquarters of the London and North Western Railway Euston Station in London, commented in his book "Registration of Correspondence. A new system applicable to large offices, etc.«:

In some offices, and by private individuals, the method of filing away letters is by means of endorsing on the back of the letter the name of the writer and date of the letter, and placing them in alphabetical pigeonholes. ${ }^{22}$

There is plenty of evidence that this system was widely used across the whole British administration. For example when Alexander MacLeay was appointed Colonial Secretary of New South Wales in 1825 he began the systematic registration of correspondence, and set aside a room, referred to as sthe new Record Office`, in the Colonial Secretary's building and had it fitted up with presses containing pigeonholes for the files and bundles of papers. ${ }^{23} \mathrm{He}$ had considerable experience in the public service, having served as secretary of the Transport Board during the French Wars. ${ }^{24}$ In 1861 pigeonholes were ordered for the newly established India Office in London. ${ }^{25}$ They had ceased to be used by 1926 when the India Office advertised for sale a nest of pigeonholes. ${ }^{26}$ When they were put away, bundles of dockets were often simply stored in sacks for future reference and until not that long ago were produced in this way in the search rooms at TNA. In fact, files had been introduced in the India Office and in India itself in the $1880 \mathrm{~s}^{27}$

\section{Confidential Prints and Blue Books}

In 1817, the Commons Select Committee of Finance asked for a return of offices in the colonies. Beginning in 1822 what became known as sblue books» were distributed annually to Colonial Secretaries who were required to enter full details for that year on a wide range of matters. Blue books are akin to the General Letters from India and may well have been based on them. ${ }^{28}$ The content of blue books was explained in the Colonial Department's regulations in 1837: »The annual sblue book is a document containing specific accounts of the Civil Establishments; of the Colonial Revenue and Expenditure; and of various statistical returns «. ${ }^{29}$

Designed in Benthamite fashion to be much more ordered and intended to demonstrate publicly the rationality of the imperial bureaucracy, they fell far short of the ideal. As Sarah Preston notes: "Although a standard book was sent out to each colony, the extent to which they were filled in, and what else was included, depended on the individual responsible for the task, and this could vary considerably «. ${ }^{30}$

From 1827, the Foreign Office took the innovative step of distributing printed copies of papers of significance to officials, the Cabinet and other cognate departments as Confidential Print to avoid the difficulty of finding information in the Library. After 1858, the Foreign Office Confidential Print also included material circulated from the newly established India Office. The system was adopted by the Colonial Office in 1833 and organised by regions of the world: Africa (TNA CO 879), North America (CO 880), Australia (CO 88), Eastern (CO 882), Mediterranean (CO 883), West Indies (CO 884), subjects affecting colonies generally (CO 885), Dominions (CO 886), Ireland (CO 903), Western Pacific (CO 934) and Middle East (CO 935). ${ }^{31}$ The practice grew until the 1850s when nearly every important dispatch or telegram was routinely printed. The Confidential Prints varied in format from a single page to a substantial volume, many have maps and diagrams. The documents were numbered 1-10,600 (1827-1914) roughly in order of 
printing in much the same way as the dockets on which they were based. ${ }^{32}$ The War Office adopted a similar practice from the Crimean War (1853-1856) which can be found at TNA WO33. Similarly, in India from 1830, important contents of the General Letters, which were then sent quarterly, were ordered to be reported separately. ${ }^{33}$ The contents of both the Foreign Office and Colonial Office Confidential Prints were derived largely from communications from governors and embassies. The makeup and content of communications sent by governors were prescribed so that they could be easily entered in the Confidential Prints:

Each dispatch must be docketed. The docket to specify the date and place at which the dispatch was written; the name of the writer and of the Secretary of State to whom it is addressed, the subject of the dispatch, and the number of its enclosures. ${ }^{34}$

Dispatches were to deal with only one subject and were to be sequentially numbered by the sender, just like dockets. $^{35}$

\section{Review of Registry Practice and Civil Service Reform}

The Treasury registry, what was known as the 'Fair Minute department, was reviewed by a Parliamentary Committee in 1849 :

The first steps of the process which all the Treasury Papers undergo, are, in our opinion, simple and effective, and well adapted to the peculiar constitution of the Office. Every paper is immediately on its arrival taken charge of by the Registry Department, and a further note is taken of it in that Department at every subsequent stage of its progress. There is, therefore, every practicable security that papers will not be lost sight of..$^{36}$

The committee pointed out that the numerical system of numbering dockets excluded dockets relating to "Parliamentary business and with ordinary issues of money «. ${ }^{37}$ The only drawback that the committee identified was the inadequacy of the subject indexes were impressed by the indexes to the 'Fair Minutes`, but considered them overburdened with detail. ${ }^{39}$ They recommended the formation of a >Record Department under a senior clerk to oversee reforms. ${ }^{40}$ Practice was similar in the Colonial Office. When incoming letters had been registered, they were passed to the senior clerk in the relevant department to minute them and propose a form of reply. ${ }^{41}$ The Irish Office registry, which was located in the Library, was judged to be "by no means perfect" and that there was considerable room for improvement. Papers more than 10 years old still remained in the departments and had not been registered..$^{42}$ In the Board of Trade, registers were fragmented across five departments until a committee of inquiry proposed that all correspondence should be entered in a single register and a transcript "be laid upon the table of the President of the Board of Trade the following morning « ${ }^{43}$ Similarly, in the Colonial Office, papers were registered under the three divisions and then bound together in books, making retrieval difficult. ${ }^{44}$ This state of affairs was symptomatic not due to inefficiency but due to lack of resources.

Before the Northcote-Trevelyan reforms in 1853, young civil servants spent many of their initial years

in copying papers, and other work of an almost mechanical character. In two or three years he is as good as he can be at such an employment. The remainder of his official life can only exercise a depressing influence on him, and renders the work of the office distasteful to him. ${ }^{45}$

Anthony Trollope in his novel »The Three Clerks " poked fun at such work in the registry:

My heart's at my office, my heart is always there -

My heart's at my office, docketing with care;

Docketing the papers, and copying all day,

My heart's at my office, though I be far away. ${ }^{46}$

An investigation of the Colonial Office suggested that no one in their right mind would have wished to be in the registry:

Much of the accommodation for the clerks is most inconvenient and unsuitable, the copyists and their 
Superintendent carry on their occupation in cellars the dampness, closeness, and darkness of which must be very injurious to their health. ${ }^{47}$

The Northcote-Trevelyan report rejected what would later have been termed a common typing pool for all Whitehall departments, electing instead to retain registries in each department, but recommending the transfer of lower grade staff, who undertook registry work, between divisions and departments. ${ }^{48}$

\section{Jacketing and the Birth of the File}

In most of the home civil service from the middle of the $19^{\text {th }}$ century, more important documents were placed in jackets, which carried the endorsement on the outside cover, and stored flat instead of being folded as had been the case before. The jacket was attached to the docket by means of what became known as a Treasury tag (a piece of string with a metal fastener at either end). This practice when coupled with long papers bundles resulted in the emergence of the file, as we know it, but at first the practice was "one letter [docket] one jacket . ${ }^{49}$ As the "Notes for the Use of Registry Branches « published by the Treasury in 1919 explained:

\begin{abstract}
The jacket or file cover is historically a survival of the eighteenth-century double sheet of foolscap, on which was written a minute, giving the instructions as to the action to be taken or the reply to be sent, and that minute, before the general introduction of the letter copying press, served as the only record of the reply..$^{50}$
\end{abstract}

The Treasury tag is only very loosely connected with the system of using wire, string or bill hooks to hold together legal documents and more commonly financial records, which was common throughout Europe from Medieval times.

\section{Function of the Registry}

In the home civil service, each department administered and still administers its own registry. Sir William the registry, where papers were referenced and docketed, as "the mainspring of the office «. ${ }^{51}$ Apart from providing an accurate journal of transactions and thereby precedent, the registry also protected the impartiality of civil servants as the records were managed by registry clerks who were, after the Northcote-Trevelyan reforms, drawn from lower division of the civil service with little prospect of promotion. ${ }^{52}$ There were elaborate safeguards to ensure fiduciary protection: documents and later files had to be signed in and out; papers could only be filed or docketed by an authorised registry clerk and all those who consulted a file or docket had to leave a record. Such arrangements represented the classic distinction between the front and back office and the fiduciary protection it affords. It, however, militated against the use of the registry as a resource for research and policy development.

At the Foreign Office, the Ridley Commission on the Civil Establishment ${ }^{53}$ recommended that the indexed registers in the Library should be discontinued and the diaries should be replaced »by a more detailed register of all the papers, that this register should be duly entered up and indexed every day, and at the expiration of two years, the papers, with the registers and indices complete, should be handed over to the Librarian «. ${ }^{54}$ Although these recommendations appeared sensible, they were a complete failure as departments did nothing to improve the quality of their diary entries and in practice indexing was abandoned. From 1891 to 1900, there was no index of Foreign Office correspondence. The Library resumed indexing, but not at the level it had between 1810 and 1890. Meanwhile, the volume of correspondence was escalating from 37,700 letters in 1890 to 54,300 in $1905 .{ }^{55}$ A central registry, along the lines of that in the Treasury, was established in 1906 following the report by the Cartwright committee and represented the final step in the modernisation of the department that had started when Lord Lansdowne was Foreign Secretary (1900-1905). ${ }^{56}$ All correspondence was to be indexed in the central registry and printed every 5 years for speed of reference. ${ }^{57}$ Reform was driven through by Eyre Crowe, who was German by birth and was previously assistant to the supervisor of the African Protectorate. This should have had far-reaching consequences for the way in which the Foreign Office was managed. ${ }^{58}$ However, it was no 
more successful as the Treasury refused to sanction the necessary increase in staff, largely because it was engaged in a wider argument across the whole civil service about the introduction of the typewriter and the employment of women clerks to replace boy copyists in an effort to improve the efficiency of registries. Like other departments, the Foreign Office was reluctant and the women when employed were confined to an attic room and only communicated by means of a hand lift. ${ }^{59}$ Indexing did not match expectation as there was no central coordination or supervision by the Librarian. ${ }^{60}$ As the international situation deteriorated, the volume of correspondence accelerated. The central registry turned out to be a "giant bottleneck" with too much business for the staff to handle. ${ }^{61}$ Even after improvements in indexing were introduced in 1910, matters did not greatly improve as there were often backlogs. ${ }^{62}$ By 1914 the whole registry system was near collapse. ${ }^{63}$

\section{Record-Keeping in the Empire}

Central registration and improved indexing were mapped out to embassies and dependent territories within the Foreign Office's jurisdiction. The filing scheme for Zanzibar survives in the British Library. The introduction stipulated that:

Each subject is allotted one file and one number. Inward and outward letters belonging to a particular file bear the number of that file, the date being the distinguishing factor. Correspondence, whether in the nature of minutes or letters, is arranged in files in chronological order from left to right after the fashion of a book and each minute, letter, etc., is numbered in a continuous series for convenience of reference.

To keep track of correspondence a daily register is kept of all incoming and outgoing communications, and a main register for the files, the system being based on book-keeping by double entry. ${ }^{64}$

Alistair Tough and Paul Lihoma could find no explanation as to where this elaborate filing schema originated but suggested that there might have been
Colonies. ${ }^{65}$ It is much more likely that it was the handiwork of Eyre Crowe with his background in East African administration.

In India, Lord William Bentick, when he was Governor General from 1828 to 1835, introduced »a system of reporting the whole of the proceedings of the officers of the diplomatic departments, the Residents and the Agents ${ }^{66}$ Sir Charles Trevelyan, as a junior official in the East India Company, explained how:

One of my first employments at Delhi was keeping the diary, as it was called, of the Delhi Residency. Each English and Native letter, each proceeding in whatever language, went into the diary, in such a form as was practically found to be sufficient to enable the Supreme Government to exercise the most effective control. ${ }^{67}$

Just as with the Treasury's Fair Minutes, the diaries became overburdened and costly to keep. The East India Company, apart from administering India, was essentially a commercial enterprise managed like any other large business through the ledgers kept in London. Given the extent of the enterprise, it produced a vast accumulation of paper that were to become the bane of the lives of Indian civil servants. These have been analysed by Bhavani Raman in "Document Raj", in which she develops the notion of "papereality" or the reliance on documents to represent the world. ${ }^{68}$ George Aberigh-MacKay, who famously satirised this practice in his "Twenty one days in India ", claimed the government secretary "inquired into everything; he wrote hundredweights of reports; he proved himself to have the true paralytic ink flux [...]. He would write ten pages where a clodhopping collector would write a sentence«. He described »the Indian Government being a despotism of dispatch-boxes tempered by the loss of keys «. ${ }^{69}$ However, 'papereality was true from very earliest times in great trading companies, otherwise it would have been impossible as Cantillon famously explained to manage arbitrage across exchanges. ${ }^{70}$ The nearest analogy in the British civil service would be either the Board of Ordnance (which supplied munitions and equipment to the army and navy, 1540s to 1855) or the Victualling Board (which supplied food to the navy, 1683-1832) both of which produced masses of paperwork covering the range and extent of their 
purchases. Because both boards interacted with a large number of suppliers and contractors throughout the whole of the United Kingdom and dealt at least in wartime with big budgets, their records like those of the East India Company were much more akin to commercial enterprise than departments of state.

A central registry was established in the India Office in the wake of Indian Revolution in 1859 by Sir Charles Wood (viscount Halifax) when he was Secretary of State:

Directions for the Transaction of Business in the India Office

A Registry Department will be constituted for the receipt and despatch of letters. A small staff of copying clerks will be attached to the Registry Department for the general copying work of the Office. Each Department will have such a number of clerks attached to it as will be sufficient for all ordinary business transacted in it. ${ }^{71}$

Although all letters were supposed to pass through the new registry, it was a registry only in name, as in other departments of the administration individual departments maintained their own registries. F. Charles Danvers, superintendent of the Records and Registry Department, condemned it as useless in 1878 when he began a systematic overhaul of the whole system. ${ }^{72}$ For all its shortcomings, he admired the Foreign Office registry. Charles Markham, whose work complemented Danvers, described the Office's records as being in a state of chaotic confusion through the lack of systematic classification. ${ }^{73}$ The emphasis of the Records Committee appointed by the Government of India in 1861 was the destruction of vast accumulations of records that were deemed to be useless, presumably much of the detailed paperwork that Raman analysed. There was a conscious decision to extinguish all trace of its commercial past and huge quantities of commercial records were destroyed and portray the Company as "a socio-geographical agent of empire ${ }^{74}$ Within a few months of taking office in 1884 at the India Office Sir Arthur Godley, who never visited India or showed any inclination to do so, ${ }^{75}$ established a more sophisticated central registry with three main branches, dispatch and copying, registry and record, to not until 1891 that the Imperial Records Department (IRD) was established in India with two objectives: first the recognition of "the archive as an instrument of governance " and secondly the promotion of the "British Imperial Image and the interpretation of the past of the Indian Empire «. ${ }^{77}$ The establishment of what was in effect, a central registry as well as record office, sparked tension between the government in Calcutta and officials at a local level who were irritated by the mass of old records cluttering their departments. Progress was frustratingly slow. Responding to a query from the viceroy Lord Curzon in 1904, C. R. Wilson, head of the IRD, explained that little had been done to bring records together, let alone catalogue them and make them available to the public. Curzon was appalled by the overburdened files that crossed his desk which he described as a ssort of literary Bedlam‘. He complained what is the difference? that he "did not need to know the personal impressions of opinion of everyone in the department of everything that comes up «. ${ }^{78}$ Curzon's response was to replace Wilson with a new recruit from the United Kingdom. No doubt following the example of the Foreign Office and the Treasury (see below), fresh India Office Procedures were published in 1910 that laid out very specific rules for filing in strict chronological order with detailed rules for arrangement with the submission docket as the top paper, followed by the minute, draft letters, dispatches and finally previous papers. ${ }^{79}$ In 1911, the IRD moved to a purpose-built repository in New Delhi, but it was not until the Indian Historical Records Commission was established in 1919 that tentative steps were taken to transfer provincial government records to the IRD and district records to provincial archives. In keeping with developments in the Foreign Office and the Treasury, a new memorandum on Indian Office Administration was circulated in 1919, a component in the reforms implemented in the Government of India Act. ${ }^{80}$

\section{Overhauling the Registries and the First World War}

The Treasury registry was completely overhauled in 1909, and the familiar manila files were introduced. The new system was explained in a memorandum written 
by the permanent secretary himself, Sir George Murray, which laid down simple unambiguous procedures ${ }^{81}$ :

The papers in the file should be arranged in chronological order beginning with the letter, minute, or other documents which originated the file, together with its enclosures if any.

Only papers which it is necessary or desirable to keep permanently on the file should be treated in this way. Other memoranda or enquiries should be written on separate pieces of paper, which should be detached immediately when they have served their purpose. ${ }^{82}$

This methodology, with supporting hierarchical filing schemes and numeric codes, was quickly adopted in some shape or form across the whole Civil Service. Each department of government was left to devise a system best suited to its needs. ${ }^{83}$ Even after filing was introduced, senior officials continued to keep letter books of outgoing correspondence bound in date order. Files, just like the long bundles that preceded them, could remain sopen for many years when they were stored on racks, akin to pigeonholes, for easy access in the registry. The novelist John le Carre, who had himself worked in the British security services, described in »Tinker, Tailor, Soldier, Spy « gleaning information from government files. In one chapter, Smiley's accomplice Guillam steals a file from the registry of the Intelligence Service. The file's reference is $4482 \mathrm{E}$. ' $\mathrm{E}$ < meant extinct and referred to closed operations. 44 « meant alcove 44 , > 8 , was the number of the pigeonhole and $>2$ « was the second file in that pigeonhole. However, when Smiley needed to gain information which could not be found in the registry, he went to Oxford to interview a retired researcher who was famous for her prodigious memory. In real life in the 1930s, the staff in Cabinet Office had to rely on the 'prodigious memory، of Sir Rupert Hepworth to help them locate files. ${ }^{84}$

On the outbreak of the First World War, it quickly became apparent that the armed services lacked an effective supply chain for the production of munitions necessary to fight a prolonged campaign. Under pressure from Lloyd George, the Ministry of Munitions was established in May 1915. Unusually, it was to be staffed by men with experience of managing logistics, mostly railways and shipping, and engineering and shipbuilding. ${ }^{85}$ Major General Sir Percy Girouard was placed in overall direction of munitions supply. He had cut his teeth as a railway administrator in his native Canada and then been a director of military railway traffic in Egypt and South Africa. He next became a controversial colonial governor in Nigeria and then the British East African Protectorate, and after his resignation in 1912, a director of the armaments company Armstrong, Whitworth \& Co. ${ }^{86}$ Nevertheless, despite the complex supply chains of the munitions that were to be procured by the new ministry, at the beginning there was little effective coordination between what quickly became a sprawling organisation. Christopher Addison, the Parliamentary Secretary to the Ministry, complained about the behaviour of both Girouard and George Booth in his diary - "After they had indulged in a good deal of 'high falutin « nonsense as to the big-businessman's methods, I brought up the fact that their registry was the most inefficient in the whole Ministry, that papers sent to them were lost and that, as a result, things were hung up and delayed «. ${ }^{87}$ As the history of the ministry noted:

Only gradually was it realised how inevitably such a lack of coordination would result in overlapping of effort with its attendant evils; and that the despised sprocedures of a Government Department, and in particular the operation of an independent central registry for recording and transmitting of documents, clumsy and dilatory though its operations might appear, did in fact offer the best possible guarantee for overcoming the tendency of branches to become isolated compartments and for securing the interchange of essential information ${ }^{88}$

Reflecting on his experience as Director General of the Trench Warfare Supply Department, Sir Alexander Roger, whose background was in investment management and communications, ${ }^{89}$ wrote:

When I joined the department, I found that a Registry Clerk had been attached to it, a man from the Board of Education who was well acquainted with the management of a Government Registry. As in the matter of contracts, I was unacquainted with the filing methods of a Government Department, and 
one day asked this clerk what his duties were and suggested that he should make out a statement of what his Registry meant and what it involved. He did so, and I took his report home for a weekend and realised at once that a commercial system however good would not fit in with the systems in vogue in the other Government Departments with which we were in hourly contact. Without hesitation, therefore cumbersome as the system appeared to me to be, I told Mr. Barber to run a Registry on the lines that he had laid down. I am glad to be able to say that the system so initiated has worked wonderfully well. It and similar systems are in some degree unwieldy but seem better able to stand the test of time, and the Registry on Civil Service lines allows papers to be traced in and between Government offices much more easily than by the ordinary filing system.

It was, however, a long time before these simple truths were generally recognised by those who were unfamiliar with Government Office procedure, and the department suffered not a little from the lack of attention and support which the Registry system received. ${ }^{90}$

Sir Graham Greene, the Ministry's secretary, had oversight of the registries. As he had previously been secretary of the foreign intelligence committee in the Admiralty, he would also have been very familiar with the need for precise record-keeping. Registry clerks were soon employed in every section. The central registry housed officially registered and indexed papers, while the satellite registries in every section held unregistered papers. ${ }^{91}$ These were referenced by file title, but not indexed. For example, D.A.O./Misc./1251,1394; D.A.O./Bds./26;D.A.O./F./l are references to Sir James Stevenson's unregistered papers. ${ }^{92}$ Very quickly, there was another motive behind the central registry and its branches in the departments: the writing of a history of the ministry. This was influenced by the ideas of the Reconstruction Committee of the War Cabinet which instructed departments in July 1916 "to maintain a complete record of administrative action during the war for the future compilation of a War Book «. ${ }^{93}$ This was a new departure for record-keeping in the home civil service, but redolent of practice in India and, probably, colonial administrations, where the purpose was to provide evidence that shed a favourable light on the British administration of the Empire. ${ }^{94}$ Despite its meticulous record-keeping, the majority of the files of the Ministry of Munitions were destroyed after the war and only those kept by the Historical Records Branch and used in compiling the history retained. These are to be found at TNA in the series MUN5. There were similar systems introduced in other wartime departments, such as the Ministry of Food and the Ministry of National Service, which had to deal with a similar flood of paperwork. ${ }^{95}$

\section{The Foreign Office at War}

The war created even greater chaos at the Foreign Office. In January 1918, Alwyn Parker, an able career diplomat in the Eastern department with expertise in railway management, ${ }^{96}$ was appointed Librarian urgently to address the problems in the registry. He was the first career diplomat to hold the post and quickly developed a new system of registration for the Contraband and Blockade departments, which only served to draw attention to the need to reorganise the whole registry. He was soon asked to review registration systems in other departments and large business firms, including the Ministry of Munitions and Sir Alexander Roger's former employer Lord St David's Old Broad Street Group, and to recommend how the Foreign Office registry could be improved. ${ }^{97}$ To implement his findings, new accommodation was required and, more critically, staff would need to be increased by half. When the Treasury was approached, doubts were cast on Parker's proposals. The Foreign Office reacted angrily, particularly Eyre Crowe, who had been responsible for the reforms in 1906 which had ended in failure due to Treasury intransigence. To forestall a similar fate, a small interdepartmental committee with representatives of the Foreign Office and Treasury was formed in September 1918 to investigate the registry. ${ }^{98}$ It had completed its work by November and adopted much of Parker's findings. The committee was caustic in its criticism of the failure of Parker's predecessor as Librarian to follow the guidelines prescribed in 1906 and this had been compounded by the shortage of staff. Their most stinging rebuke was for the way files were sarchived: 
Not grouped or classified on any known principle that might guarantee a right location or counter-check errors, the archives merely ran in the order of their numbers from the first number arising in the year down to the latest received, with the result that if the file number by a clerical slip be inaccurately written or be misread ... for all practical purposes the document is lost. ${ }^{99}$

There was also no means of recording papers in circulation and a huge backlog of unindexed papers. Unless these shortcomings were addressed, the committee concluded that »the efficiency of the registry is well-nigh lost «. ${ }^{100}$ Recognising that any solution would be expensive, the committee had little doubt that radical action was essential. They recommended that there should be a comprehensive registry for the whole Foreign Office which should continue to form part of the Library with adequate staffing. Just as in the India Office, with which after all it shared premises, it was recommended that the registry should consist of:

(i) a >Classification Branch`, (ii) an >Archives Branch`, (iii) a >Despatch Branch'; the duties of (i) being to open, classify, number serially, and distribute documents received; of (ii) to docket, file, and index inward and outward correspondence; and of (iii) to prepare all outward communications for signature and despatch, and to distribute the confidential print and parliamentary papers. ${ }^{101}$

Endorsements were to be dictated to shorthand copyists and four copies typed up on papers with three carbon copies to be fixed to the jacket and circulation to Under Secretaries and the other three for filing, reference and preparation of the index by the Archives with "unvaried regularity «. ${ }^{102}$ Sir Alexander Roger from the Ministry of Munitions was cited in the conclusion to emphasise the importance of the registry from a commercial perspective ${ }^{103}$ : "A registry is not an end in itself. It is a necessary, even if expensive, means of facilitating the rapid and smooth working of any large administrative machine ${ }^{104}$

The reforms were immediately approved as Lord Hardinge, who had returned from serving as Viceroy in India to his post as permanent under-secretary, wished to place the Library, in other words records, at the heart of the forthcoming Paris peace conference. ${ }^{105}$ As a result of trialling the new system at the conference, modifications were made. The Classification Branch was rebranded as the Opening Branch and many of its functions were transferred to the Archives Branch that became the heart of the Registry. The new system was formally introduced with Treasury approval in January 1920 and, despite cuts in government spending, survived almost intact until the outbreak of the Second World War. ${ }^{106}$

\section{Reorganisation of the Registry System}

In parallel with the Foreign Office registry review, the Treasury conducted a similar investigation that was designed to create, for the first time, a uniform system across the Home Civil Service and the Colonial Office. Conducted by W. T. Matthews, the review was completed by May 1919 and was accompanied by printed "Notes for the use of Registry Branches«, which was painstakingly edited and revised in consultation with permanent secretaries and registry clerks across government. ${ }^{107}$ The permanent secretary at the wartime ministry of National Service commented with a hint of sarcasm:

The need for inotes, such as you propose to issue is very obvious to those of us who have had to deal rapidly with a large correspondence. It is very obvious that a system which answers the purpose of an office where methods are leisurely and where, apparently, time is of no importance, will be useless for dealing with the very large number of files which are daily in action in a Ministry such as this. ${ }^{108}$

The "Notes" were very detailed and designed as far as possible to save unnecessary expense. Just as at the Foreign Office, they extolled the virtues of efficient filing:

The recording of documents is one of the most important features of the domestic economy of any office. Unless the records are efficient, the office machinery cannot run smoothly, the treatment of all business will be delayed and the time of all officials, 
from the highest to the lowest, wasted, while wrong decisions will be given through the absence of essential information. ${ }^{109}$

The way files were to be organised and numbered or titled in what has become known as a file plan was left to every department to decide for itself, as it had always been. ${ }^{110}$ The files themselves were to "read like a book«, with the "first letter downwards, minutes and drafts following the letter « ${ }^{111}$ The "Notes « endorsed the practice of keeping carbon copies bound sequentially in letter books for reference. ${ }^{112}$ For the first time since the Second Report of the Royal Commission on Public Records, from 1910 to $1919,{ }^{113}$ recommended that one member of the registry staff should be responsible for transmitting records to the Public Records Office (PRO now TNA), ${ }^{114}$ guidance was provided:

it may be presumed that only documents of possible public interest would be registered as archives of permanent value; unregistered papers as are earmarked for destruction when they have served a temporary purpose, need not necessarily be regarded as records.

Instructions on registration and weeding were vague. It was assumed that in an refficient department e ephemeral papers would never be registered in the first place. One of the reasons given for weeding was to prevent the PRO Repository from taking in "a cumbersome mass of useless or unnecessary documents«. ${ }^{115}$

The »Notes « were couched in terms of all departments of government and were circulated to them by Sir Michael Ramsay, permanent secretary at the Treasury, with the apparent caveat that they were

not to be taken as being in the nature of official instructions but My Lords trust they may prove of some value and They will be glad if steps can be taken to ensure that they shall be brought to the notice generally of officers engaged in actual registry work in all sub-departments or branches of the Public Service. ${ }^{116}$

Since Treasury approval would be required for any increased expenditure and an Organization and Methods
Division of the Treasury had been established, partly to scrutinise and advise on registry practice across the Home Civil Service and the Colonial Office, ${ }^{117}$ there could have been little doubt that this was as much an official instruction as Sir George Murray's a decade earlier. ${ }^{118}$ Similar "Notes for the Use of Accounts Branches" was published and circulated at the same time, along with a "Guide to the Supply etc. of Stationery" from His Majesty's Stationery Office. ${ }^{119}$

In the Treasury itself, the registers of dockets (TNA series T2) were closed in 1920 when the system of registering all Treasury papers in a single numerical series each year was abandoned, even though filing of Treasury dockets in folders had begun in 1887 (T160). ${ }^{120}$ A separate registered file series was created for each of the three new Treasury departments - finance, supply and establishment - with an additional general file series for subjects which were not attributable to any single department. Files were organised in much the same way as dockets were in the registers under broad subject headings. ${ }^{121}$ The objective, as at the Foreign Office, was to set up a central registry. The registers (T2 and T3) were replaced by card indexes by geographical location, department and correspondent. Card indexing had been introduced as Simon Fowler has shown during the war to manage huge volumes of personal data. ${ }^{122} \mathrm{~A}$ new jacket was introduced to help trace files in transit in the departments and locate them in the filing system. ${ }^{123}$

Under the new registry system, files across the civil service contained the following information on their jackets for ease of use (Fig. 7):

File reference

File name

Security classification - secret files often had a distinctive red band or other colour code across their covers.

List of related files. This could be either the previous and next file in a series or files which were related by subject. 
The colours of the jackets varied. ${ }^{124}$ In some departments, this denoted the sub-department or subject area and in others it denoted the file cycle to which a particular file belonged. Normally a file cycle would last, say 5 years, and at the end of the cycle all the current files would be 'put away، in the registry and new files would be issued with different coloured jackets. If a number of officials were working on a subject, there would be a minute sheet at the front of the file where each official could add their comments. These were colour-coded: buff for non-permanent records and white for permanent. ${ }^{125}$ Minutes usually were brief and were given initials and dated, so future researchers sometimes struggle to make out who added which comment. However, there is a clue in the colour of the inks used. Officials wrote in black ink, or blue. Ministers wrote in green ink and the National Audit Office wrote in red. Until the advent of photocopiers, files were quite thin as there were usually only one or two filed copies of a paper - a top copy and a carbon copy. The other two copies were bound in letter books. However, with the advent of photocopying everything was copied everywhere. Copies of Cabinet Minutes agreeing to certain actions are sometimes found on files.

The way of working with files was that when a new subject was being developed, for example a new Ministerial initiative, the official concerned would ask registry for a new file and this would be created and sent to the official who would keep it in a secure cupboard for as long as it was being worked on. He or she would then send it back to the registry with a note "Reg p.a. - Put Away or b.f. - bring forward" and it would then be returned to the file store. ${ }^{126}$ Periodically, the registry would conduct an audit of the cupboards to check where all the outstanding files were. In many offices, there was a guerrilla war between some officials who regarded the files as their own property and the registry who wanted to control them. As Barbara Craig observed, the preparation of the "Notes" "established a co-operative mode for developing models of practice that was favoured in the future by the Treasury's newly formed Establishment Division and particularly by its investigating officers «. ${ }^{127}$ This was patently wishful thinking.

\section{Impact on Record-Keeping in the Empire}

In the Colonial Office, again as Alistair Tough and Paul Lihoma have shown, record-keeping at a district level remained largely chaotic and haphazard, partly as a result of pressure of work and partly from a lack of inclination. ${ }^{128}$ As in New South Wales in 1825, it was in the secretariat that improvement began. In 1892, Sir Frederick Napier Broome, Governor of Trinidad, had issued regulations for official correspondence and business ${ }^{129}$ :

In the office of each department there shall be kept a register of documents received. ${ }^{130}$ [...] and [...] each department should transact its own business and conduct its own correspondence; and it is by no means desired to centralise correspondence in the Colonial Secretary's office [...]..$^{131}$

It was not, however, until the 1920s that a uniform subject-based system of filing following the Treasury guidelines began to be adopted, albeit tentatively, in the dependencies for which the Colonial Office remained responsible. ${ }^{132}$ In 1867, Canada had been granted selfgoverning status as a dominion, followed in 1901 by Australia, New Zealand and Newfoundland in 1907 and South Africa in 1910. Canada moved quickly to establish an Archives Branch in the Department of Agriculture in 1872, solely under the jurisdiction of the new federal government. ${ }^{133}$ Following the establishment of a Historical Manuscripts Commission, in 1912 a royal commission was established to inquire into the state of the Dominion public records, the nature and extent of the records, their state of preservation, the use made of them, the state of the buildings where they were to be found, the space they occupied in said buildings, the facilities for access to the records and finally the control exercised over them. Their report published in 1914 revealed the same sorry state of affairs as in the rest of the Empire. They had visited every place that departmental records were held in Ottawa, travelling from ramshackle attics to damp basements with numerous descriptions of bags of letter books, chests of accounts and piles of correspondence. ${ }^{134}$ The situation 


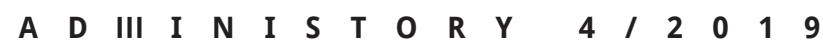

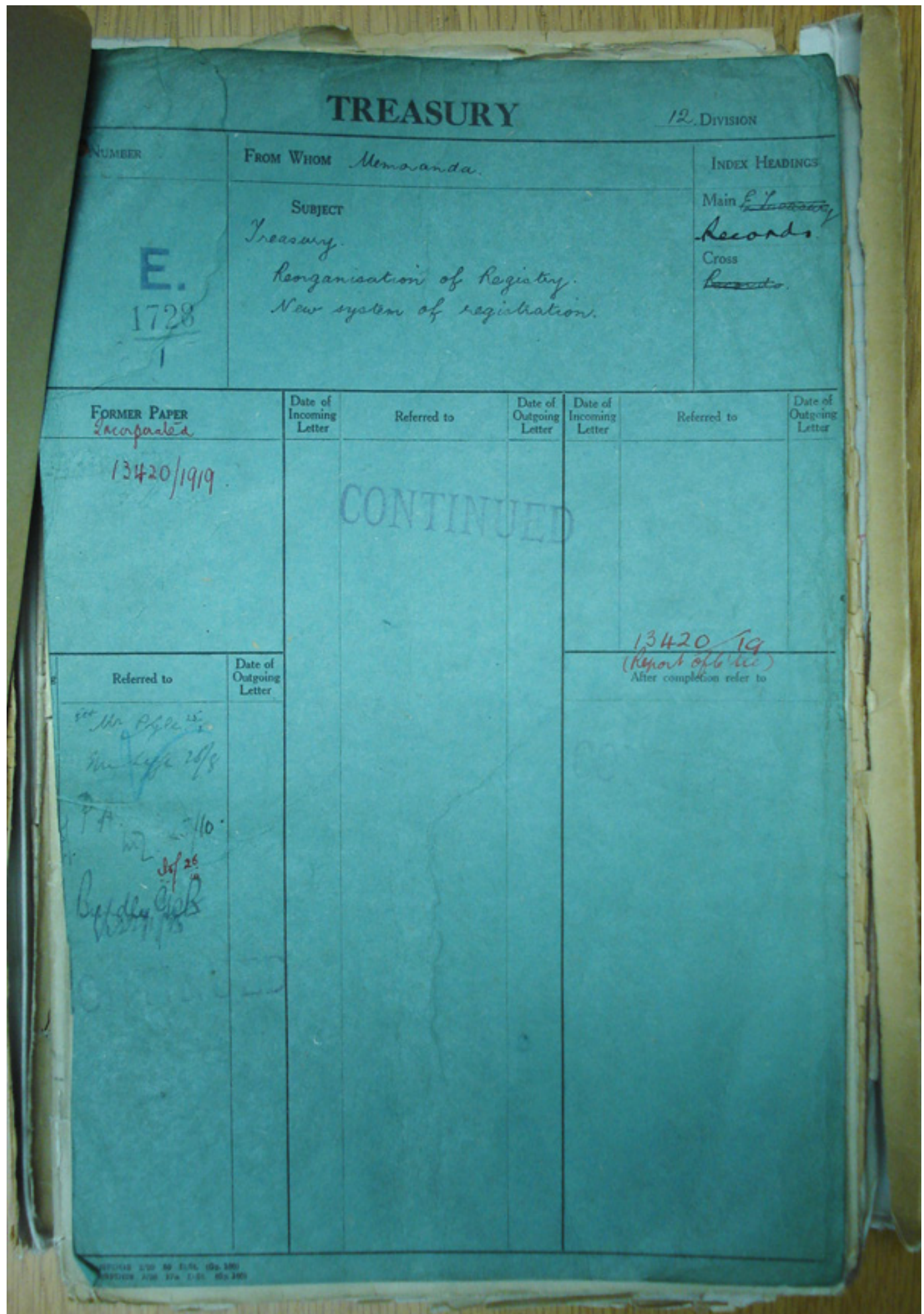

Figure 7: This is the new file cover introduced when the registry was reorganised, which the contents of this file are about. The file number is $\mathrm{E} 1728$ (the E standing for establishment) and the previous file under the old system was 13420, now T1 in TNA. (Source: TNA T1) 
in Australia was, if anything, even worse. Keith Penny discovered that after the formation of the dominion:

Governments of the day gave little thought to the records which their departments had accumulated over the years. They failed to appreciate (as commonly did their counterparts elsewhere) not only the administrative benefits of possessing a properly ordered record of past activities but also the economic consequences of not providing for the systematic selection and destruction of valueless material. ${ }^{135}$

When late in the day in 1942 a start at last was made, exactly the same state of muddle and confusion was apparent. ${ }^{136}$ It is hard to dignify such a chaotic legacy of registries as "centres of calculation«. It was TNA and other national archives that would convert them into those registries. The rest of the Dominions followed suit and the Colonial Office ceased to have any responsibility for record-keeping policy.

\section{Digital Demise}

The registry systems put in place after the First World War continued with modification and division as government business expanded throughout the $20^{\text {th }}$ century. The filing system that Sir Christopher Foster remembered had been invented but it was not without the problems as Barbara Craig has shown and was notoriously poorly staffed and resourced. ${ }^{137}$ The whole system collapsed with the advent of the digital era. This was brutally exposed in the inquiry by Lord Hutton, a judge, into the death of Dr David Kelly, the weapons expert, on 17 July 2003. Hutton took the innovative decision to post all the documents that he did not consider to jeopardise national security or disclose personal details on the web and, even where they did, he made their existence known. These illustrated just how far the registry system established after the First World War had dissolved with only faint traces of well-established registry practice. ${ }^{138}$ Subsequently Sir Alex Allan, the Prime Minister's Independent Advisor on Ministerial Standards, was asked by the Cabinet Secretary to review government digital records. His report opened with the by now time-honoured mantra but with three significant additional qualifications:

Good record management, whether of paper or digital records, is essential for good government: to support policy development, to provide accountability, to enable comprehensive evidence to be submitted to inquiries and court actions, and eventually to provide the historical background to government. ${ }^{139}$

In the past, the purpose of record-keeping in both the public and private sectors had been good governance, but Alex Allan added policy development, accountability and evidence. ${ }^{140}$ Public accountability is not the same as audit. This difference has been thrown into sharp relief by the worldwide child abuse scandals and in the United Kingdom by the Windrush case. In the latter case, in 2018, it was revealed that the UK Home Office had destroyed landing cards relating to immigrants from the Caribbean in the 1940s. These were records which were filled in when people arrived in the United Kingdom. Many of them had travelled to Britain in 1948 on the ship Empire Windrush. Although those who travelled to the United Kingdom had British citizenship, the cards were important to them in proving evidence of their status, particularly after 2012 when the UK government introduced a new, more hostile policy towards illegal immigrants and some sWindrush migrants have been deported or threatened with deportation. The destruction happened because of Home Office concerns about Data Protection. ${ }^{141}$ Such scandals have increased societal expectations for the preservation of evidence, particularly case files (known in the United Kingdom as particular instance papers - PIPs) that were routinely destroyed and only exceptionally transmitted to TNA. More or less echoing the chaos in the Foreign Office in 1918 that Crowe addressed and mindful of these changes, Sir Alex Allan commented trenchantly - »The processes have been burdensome and compliance poor «. Just as then, he called for radical change in culture "backed up by a high-level push to make sure new procedures are followed in practice«. As in the past this will be very expensive. ${ }^{142}$ Startlingly not only had little changed, the situation that if anything has got even worse with cuts in government spending and a continued reluctance by departments to give priority to managing information. 
The emergence of the file in the United Kingdom and its dominions was no journey into modernity but a necessary evil to be avoided and wherever possible circumvented.

\section{Acknowledgements}

The authors would like to thank the three peer reviewers, Sir Alex Allan, Swapan Chakravorty, John Danver, Simon Fowler, Mark Frost, Paul du Gay, Daniel German, Paul Lihoma, Alan Mackinlay, Tom Nesmith, Michael Piggott, Richard Smith and Alistair Tough for their advice and comments, and the Keeper of Public Records for permission to reproduce the seven illustrations. 
1 George Archibal Campbell: The Civil Service in Britain, Harmondsworth 1955, p. 69.

2 John Bowring: Collected Works of Jeremy Bentham, vol. 3, Edinburgh 1843, p. 33.

3 See for example Pedro Schwartz: John Stuart Mill and Laissez Faire. London Water, in: Economica, New Series 33/129 (1966), p. 71-83.

4 Walter C. Richardson: History of the Court of Augmentations, Baton Rouge 1961, p. 1536-1554.

5 Hugh Edward Egerton: A Short History of British Colonial Policy, London 1897.

6 Sabyasachi Bhattacharya: Archiving the British Raj. History of the Archival Policy of the Government of India, with Selected Documents, 1858-1947, New Delhi 2018, p. 40.

7 David Gilmour: The British in India. Three Centuries of Ambition and Experience, London 2018, p. 13.

8 Bernard Porter: The Absent-Minded Imperialists, Empire, Society and Culture in Britain, Oxford 2004, pp. 17-18.

9 Christopher Foster: British Government in Crisis, or the Third English Revolution, Portland, OR 2005, p. 26.

10 The National Archives (London) [TNA]: WO 32/9310, Comments by Lord Panmure on the formation of the War Office Registry, 1855.

11 Dorit Raines: Public or Private Records? The Family Archives of the Venetian Ruling Elite in Fifteenth-Eighteenth Centuries, in: Maria de Lurdes Rosa (ed.): Arquivos de famîlia, séculos XIII-XX. Que presente, que futuro?, Lisboa 2012, p. 535-548.

12 TNA T2 Treasury: Registers of Papers.

13 TNA T3 Treasury: Skeleton Registers.

14 Reports of Committees of Inquiry Into Public Offices and Papers Connected Therewith, London 1859, p. 48.

15 Bruno Latour: Science in Action, Boston 1988, chapter 6.

16 Foreign and Commonwealth Office [FCO] Library and Records 17821995: Historians, in: LRD 8 (June 1995), p. 3-6, https://issuu.com/ fcohistorians/docs/history_notes_cover_hphn_8

17 https://www.kew.org/science/collections-and-resources/ collections/economic-botany-collection (14. 10. 2019).

18 King's College London: The Foreign and Commonwealth Office Historical Collection, online: https://www.kcl.ac.uk/library/ archivespec/special-collections/Individualcollections/fco.aspx (14. 10. 2019): Apart from the files, the contents of the Foreign Office Library are now held by Kings College, London.

19 TNA: FO 608/151/23, Memorandum for A. J. Balfour, 1919, p. 2.

20 Janet Macdonald: The British Navy's Victualling Board, 1793-1815. Management Competence and Incompetence, Woodbridge 2010; and, for example, Nicholas Andrew Martin Rodger: War as an Economic Activity in the >Long، Eighteenth Century, in: International Journal of Maritime History 22/2 (2010), p. 1-18. There is no history of the Board of Ordnance.

21 Ibid

22 R. W. Lapper: Registration of Correspondence. A New System Applicable to Large Offices, etc., London 1870, p. 11.

23 North South Wales Government State Archives \& Records, Colonial Secretary: Historical background, online: https://www.records.nsw. gov.au/recordkeeping/colonial-secretary-introduction/colonialsecretary-introduction.

24 Dearelie Cherry: Alexander Macleay. From Scotland to Sydney, Kalnura 2012, p. 22.

25 British Library India Office Library and Records [IOR]: IOR/L/ SUR/6/28, f.16, Pigeonholes for Registry Department, 1861.

26 IOR/L/SUR/6/24/25, Sale of Nest of Pigeon Holes, 1925-1926.

27 Patrick Joyce: The State of Freedom. A Social History of the British State since 1800, Cambridge 2013, p. 175.
28 Sarah Preston: Colonial Blue Books. A Major Resource in the Royal Commonwealth Society Library, in: Bulletin of the Friends of Cambridge University Library, no. 26-27 (2006-2007), online: https://www.lib.cam.ac.uk/collections/departments/royalcommonwealth-society/projects-exhibitions/colonial-blue-booksmajor (14. 10. 2019).

29 Colonial Office: Rules and Regulations for the Information and Guidance of Principal Officers and Others in His Majesty's Colonial Possessions, London 1837, p. 51.

30 Preston: Colonial Blue Books.

31 http://discovery.nationalarchives.gov.uk/details/r/C438 (14. 10. 2019).

32 https://libguides.bodleian.ox.ac.uk/op/cp (14. 10. 2019).

33 Bhattacharya: Archiving the British Raj, p. 47.

34 Colonial Office: Rules and Regulations, p. 84.

35 Alistair Tough / Paul Lihoma: The development of recordkeeping systems in the British Empire and Commonwealth. 1870s-1960s, in: Archives and Manuscripts 40/3 (2012), p. 191-216.

36 Reports of Committees, p. 28.

37 Ibid., p. 29.

38 Ibid., p. 29.

39 Ibid., p. 30.

40 Ibid., p. 31.

41 Ibid., p. 48.

42 Ibid., p. 74.

43 UK Government Report from the Select Committee on Indian Territories: Together with the Proceedings of the Committee, Minutes of Evidence and Appendix, vol. 3, London 1853, p. 46.

44 Reports of Committees, p. 47-61.

45 UK Government Report on the Organisation of the Permanent Civil Service, London 1854, p. 6.

46 Anthony Trollope: The Three Clerks. A Novel, London 1858.

47 Reports of Committees, p. 60.

48 Report on the Organisation of the Permanent Civil Service, p. 17-18.

49 TNA T199/90, Memo G. R. Hamilton to Sir Warren Fisher, December 1919.

50 TNA T1/12334, 14, Notes for the use Registry Branches, London 1919.

51 Second Report of the Royal Commission on Civil Establishments, Minutes of Evidence, London 1888, C.5545, xii, 195.

52 See, for example, Seán McConville: English Local Prisons, 1860 1900. Next Only to Death, London 1994, p. 515.

53 »Fourth Report of the Royal Commission appointed to inquire into the Civil Establishments of the different offices at home and abroad«, London 1890 (Cmd. 6172).

54 Michael Roper: The Records of the Foreign Office, 1782-1968, London 2002, p. 34.

55 TNA FO 608/151/23, p. 3.

56 Francis Harry Hinsley: British Foreign Policy under Sir Edward Grey, Cambridge 1977, p. 23.

57 TNA FO 608/151/23, p. 3.

58 Zara Steiner: The Old Foreign Office. From a Secretarial Office to a Modern Department of State, in: Opinion publique et politique extérieure en Europe. I. 1870-1915, Actes du Colloque de Rome (13-16 février 1980), Rome 1981, p. 177-195, at pp. $189 f$.

59 Gertjan De Groot / Marlou Schrover: Women Workers and Technological Change in Europe in the Nineteenth and Twentieth Century, London 2005, p. 75-76, 79 and 80, online: https://www. taylorfrancis.com/books/9780203991084 (30. 07. 2019).

60 TNA FO 608/151/23, 1918, p. 3.

61 Ibid., 1919, p. 4. 
62 Hinsley: British Foreign Policy, p. 3 and 64.

63 Steiner: Grey, Hardinge and the Foreign Office. 1906-1910, in: The Historical Journal 10/3 (1967), pp. 415-439, at p. 436.

64 Government of Zanzibar: Classification and Filing of Correspondence, Zanzibar 1914, a copy

65 Tough / Lihoma: The development, p. 583.

66 "Third Report from the Select Committee on Indian Territories with minutes of the Evidence«, London 1853, p.46.

67 Ibid.

68 Bhavani Raman: Document Raj. Writing and Scribes in Early Colonial South India, Chicago 2012, p. 3.

69 George Aberigh-Mackay: Twenty-one Days in India or the Tour of Sir Ali Baba, KCB, London 1881, p. 41, cited in Gilmour: The British in India, p. 173.

70 Anthony Brewer: Richard Cantillon. Pioneer of Economic Theory, London 1992.

71 IOR/W 7804(e), Directions for the Transaction of Business in the India Office, 1859.

72 Joyce: The State of Freedom, pp. 175-177.

73 Ibid., p. 182.

74 Ibid., p. 180.

75 Gilmour: The British in India, p. 13.

76 Arthur B. Kaminsky: The India Office. 1880-1910, Westport, CT 1986, pp. 19-20.

77 Bhattacharya: Archiving the British Raj, pp. 91-92.

78 Gilmour: The British in India, pp. 173-174.

79 Kaminsky: The India Office, pp. 163 and 167.

80 IOR/ L/PO misc. 5, memorandum on Indian Office Administration, 1919.

81 A copy can be found at TNA T199/90 Committee on Treasury Registry Report.

82 It was understood that great care had to be taken when deciding not to register papers, because they would be snot always freely accessible to others having a legitimate interest in them‘. National Archives of Scotland, SOE 4/65, Review of Registry Services by Organisation and Methods Division of HM Treasury, February 1961, p. 5.

83 SOE $4 / 65$, p. 2.

84 TNA CAB 21/2387, Memorandum, Hastings Ismay to Sir Rupert Hepworth, 12 August 1937.

85 Wayne Osborne: Manufacturing and The Great War, unpublished PhD thesis, Loughborough University 2013, pp. 47-49, online: https://dspace.Iboro.ac.uk/dspace-jspui/bitstream/2134/12550/3/ Thesis-2013-Osborne.pdf (14. 10. 2019).

86 John Flint: Girouard, Sir (Édouard) Percy Cranwill (1867-1932), in: Oxford Dictionary of Biography, Oxford 2004, online: http://www. oxforddnb.com/view/10.1093/ref:odnb/9780198614128.001.0001/ odnb-9780198614128-e-33415 ?rskey $=$ LXZNjh\&result $=2$ (14. 10. 2019).

87 Quoted in Kathleen Burk (ed.): War and the State. The Transformation of British Government, 1914-1919, London 2014, p. 41.

88 Ministry of Munitions, Munitions Council: Historical Records Branch, Official History of the Ministry of Munitions, HMSO, London 1915-1922, p. 155.

89 Graces Guide to British Industrial History, online: https://www. gracesguide.co.uk/Alexander_Roger.

90 Ministry of Munitions, pp. 155-156.

91 Ibid., p. 179.

92 Ibid., p. 40

93 Denys Hay: The Official History of the Ministry of Munitions, in: The Economic History Review a14/2 (1944), pp. 185-190, at pp. $185 f$.
94 Bhattacharya: Archiving the British Raj, p. 92.

95 See, for example, in TNA T1/12334: W. L. Hands permanent secretary of the Ministry of National Service to A. T. V. Robinson a member of the Treasury review committee, 24 May 1919, and R. E. Thornley, permanent secretary at the Ministry of Food to A. T. V. Robinson, 7 April 1919.

96 Zara Steiner: The Foreign Office and Foreign Policy. 1898-1914, Cambridge 1969, p. 121; and Foreign Office Lists: FCO, London 1920. There is confusion in some sources about the date of his appointment.

97 TNA FO 366/758. Memorandum by Foreign Office, The Records of the Foreign Office, 1918, p. 67.

98 FO 608/151/23, p. 5.

99 Ibid., p. 4-5.

100 Ibid., p. 5.

101 Ibid., p. 6.

102 Ibid., p. 6-7.

103 TNA F0366/787 report of committee on the reorganization of Foreign Office Registries, 14 November 1918.

104 Appendix part 1, para 1.

105 Foreign and Commonwealth Office Historians: FCO Library \& Records 1783-1995, in: History Notes by FCO Historians, 8 (June 1995), p. 13.

106 Zara Steiner / Michael L. Dockrill: The Foreign Office Reforms, 1919-1921, in: The Historical Journal 17/1 (1974), pp. 131-156, at pp. $146-151$.

107 TNA T1/12334, Memorandum to Sir Michael Ramsay, May 1919. A copy can be found at T199/90.

108 TNA T1/12334, W. L. Hands permanent secretary.

109 TNA T162:82:17, Notes for the use of Registry Branches, 1919, p. 8. 110 Ibid., pp. 8-9.

111 Ibid., p. 15.

112 Ibid., p. 23.

113 The Commission was active from 1800 to 1837, The Public Record Office was established in 1838, see John D. Cantwell: The Public Record Office, 1838-1958, London 1991.

114 Cmd. 7544, Second Report of the Royal Commission on Public Records, 1914.

115 TNA T1/12334, Notes, p. 27.

116 TNA CO 323/806/8, Sir Michael Ramsay to all departments, 8 July 1919.

117 Interestingly there is no evidence that the notes were circulated to Dominion Governments so arm's length had the relationship become.

118 Henry Rosevaere: The Evolution of a British Institution. The Treasury, London 1969, p. 246.

119 TNA T2/12195/35337, a copy can be found at T199/90.

120 A copy can be found in TNA T199/90, Committee on Treasury Registry Report.

$121 \mathrm{http}: / /$ discovery.nationalarchives.gov.uk/details/r/C13897 (14. 10. 2019)

122 Simon Fowler: >A Machine for Warı - the Origins of the Card Index, Magazine of the Friends of The National Archives 30/1 (2019).

123 Barbara L. Craig: Rethinking Formal Knowledge and its Practices in the Organization. The British Treasury's Registry Between 1900 and 1950, in: Archival Science 2/1 (2002), pp. 111-136, at p. 126.

124 TNA T1/12334, 14, Notes, p. 30.

125 Ibid., p. 31.

126 Ibid., p. 26.

127 Craig: Rethinking Formal Knowledge, p. 124.

128 Tough / Lihoma: The development, p. 204. 
129 TNA CO 295/337, Colonial Office minutes on Trinidad Government, Regulations for official correspondence and business, Government Printing Office, Port-of-Spain, 1892, f. 170, cited in Tough / Lihoma: The development, pp. 196 and 206.

130 TNA CO 295/337, f. 170, at para 55.

131 Ibid., at para 95.

132 Government of Nyasaland, Regulations for the Conduct of Official Correspondence, 1922, National Archives of Malawi [NAM] NC 1/1/3; and Tough / Lihoma: The development.

133 Jay Atherton: The Origins of the Public Archives Records Centre, 1897-1956, in: Archivaria 8 (Summer 1979), pp. 35-59.

134 Joseph Pope: Report of the Royal Commission appointed to Inquire into the State of the Records of the Public Departments of the Dominion of Canada. Ottawa 1914, online: http://epe.lacbac.gc.ca/100/200/301/pco-bcp/commissions-ef/pope1914-eng/ pope1914-eng.htm; It may also be found at http://publications. gc.ca/site/eng/9.827562/publication.html (14. 10. 2019).

135 Keith Penny: Factors in the administration and use of Australian departmental archives, unpublished PhD thesis, Australian National University 1962, p. 9.

136 Penny: Factors in the administration, pp. 41-42.

137 Craig: Rethinking Formal Knowledge.

138 Michael Moss: The Hutton Inquiry, the President of Nigeria and What the Butler Hoped to See, in: English Historical Review 120/487 (2005), pp. 577-592; and Michael Moss: Where Have All the Files Gone? Lost in Action Points Every One?, in: Journal of Contemporary History, 47/4 (2012), pp. 860-875.

139 Sir Alex Allan, Review Of Government Digital Records, 2015, summary, para 3 a, online: https://assets.publishing.service. gov.uk/government/uploads/system/uploads/attachment_data/ file/486418/Report_-_Digital_Records_Review.pdf (14. 10. 2019).

140 Allan: Review of Government Digital Records, London 2015, online: https://assets.publishing.service.gov.uk/government/uploads/ system/uploads/attachment_data/file/486418/Report_-_Digital_ Records_Review.pdf (30. 09. 2019).

141 Georgina Lee: Who Destroyed the Windrush Cards, in: FactCheck, 24. 04. 2018, online: https://www.channel4.com/news/factcheck/ factcheck-who-destroyed-the-windrush-landing-cards (30. 07. 2019).

142 Allan: Review of Government Digital Records, London 2015, summary, para 3 c, online: https://assets.publishing.service. gov.uk/government/uploads/system/uploads/attachment_data/ file/486418/Report_-_Digital_Records_Review.pdf (30. 07. 2019). 


\section{Abstract}

The file is synonymous with British bureaucracy but it had a long gestation from at least the $16^{\text {th }}$ century. It emerged slowly from the chrysalis of the docket during the $19^{\text {th }}$ century, differentially in the various departments of state and became a fixity following reforms in the aftermath of the First World War. Even then the system of recording information in government was not uniform and was subject to the exigencies of the financial crisis and the commitment of officials. Although India and the rest of the Empire had separate administration, there was very little attempt to manage and preserve information effectively. Most initiatives met only with partial success and were often resented by junior officials. Registries in keeping with longheld commitment to paucity in government spending were and are poorly staffed and resourced. This article traces the evolution of the file until its demise in the digital age.

\section{About the Authors}

Michael Moss is emeritus professor of archival science at the University of Northumbria. He was previously research professor in archival studies in the Humanities Advanced Technology and Information Institute at the University of Glasgow, where he directed the Information Management and Preservation MSc programme. Prior to being appointed to HATII, he was archivist of the University from 1974 to 2003. He was educated at the University of Oxford and trained in the Bodleian Library. He was Miegunyah Distinguished Visiting Fellow in the e-Scholarship Research Centre at the University of Melbourne in 2015. He researches and writes in the fields of history and the information sciences. His recent publications include: edited with Barbara Endicott Popovsky "Is the Digital Different«, Facet Press 2015, „Understanding Core Business Records« in Alison Turton (ed) »International Business Records - Handbook«, Routledge 2017 and with David Thomas and Tim Gollins, "The Reconfiguration of the Archive as Data to Be Mined", in: Archivaria 86, Fall 2018, and "Artificial Fibres - The Implications of the Digital for Archival Access«, in: Frontiers in Digital Humanities, 2018.

DAVID Thomas is visiting professor at Northumbria University. Previously, he was Director of Technology at the UK National Archives where he was responsible for records management and the delivery of online catalogues and records. He was educated at London University and did a PhD in Tudor history under Conrad Russell. He researches and writes in the field of archives and history. His recent publications include: with Valerie Johnson, »From the Library of Alexandria to the Google Campus: Has the Digital Changed the Way We Do Research?«, in: Michael Moss and Barbara Endicott Popovsky (eds): »Is the Digital Different«, Facet Press 2015; with Valerie Johnson and Simon Fowler, The 'Silence of the Archive`, Facet, 2017, with Michael Moss, "Overlapping Temporalities: The Judge, the Historian and the Citizen«, in: Archives, 52, 2017, with Michael Moss, "The Accidental Archive«, in: Caroline Brown (ed): »Archival Futures«, Facet 2018. 